CHILDREN IN THE FILMS OF ALFRED HITCHCOCK 
This page intentionally left blank 


\title{
Children in the Films of Alfred Hitchcock
}

\author{
Edited by \\ Debbie Olson
}




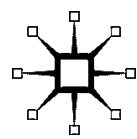

CHILDREN IN THE FILMS OF ALFRED HITCHCOCK

Copyright (C) Debbie Olson, 2014.

Softcover reprint of the hardcover 1st edition 2014

All rights reserved.

First published in 2014 by

PALGRAVE MACMILLAN ${ }^{\circledR}$

in the United States-a division of St. Martin's Press LLC,

175 Fifth Avenue, New York, NY 10010.

Where this book is distributed in the UK, Europe and the rest of the world, this is by Palgrave Macmillan, a division of Macmillan Publishers Limited, registered in England, company number 785998, of Houndmills, Basingstoke, Hampshire RG21 6XS.

Palgrave Macmillan is the global academic imprint of the above companies and has companies and representatives throughout the world.

Palgrave ${ }^{\circledR}$ and Macmillan ${ }^{\circledR}$ are registered trademarks in the United States, the United Kingdom, Europe and other countries.

ISBN: 978-1-137-47554-1

Library of Congress Cataloging-in-Publication Data

Children in the films of Alfred Hitchcock / edited by Debbie Olson.

pages $\mathrm{cm}$

Includes bibliographical references and index.

ISBN 978-1-137-47554-1 (hardback)

1. Hitchcock, Alfred, 1899-1980-Criticism and interpretation.

2. Children in motion pictures. 3. Motion pictures-Social aspects.

4. Motion pictures-Psychological aspects. 5. Motion pictures-

Political aspects. I. Olson, Debbie C., 1961-

PN1998.3.H58C45 2014

791.4302' 33092-dc23

2014026636

A catalogue record of the book is available from the British Library.

Design by Newgen Knowledge Works (P) Ltd., Chennai, India.

First edition: December 2014

109876554321

ISBN 978-1-349-50185-4 ISBN 978-1-137-47281-6 (eBook)

DOI $10.1057 / 9781137472816$ 
For Lyn and Liabna 
This page intentionally left blank 


\section{Contents}

List of Illustrations $\quad$ ix

Introduction

Alfred Hitchcock's Children

Debbie Olson

Chapter 1

Alfred Hitchcock's Missing Children: Genre, Auteurship, and Audience Address

Noel Brown

Chapter 2

"The Future's Not Ours to See": How Children and Young Adults Reflect the Anxiety of Lost Innocence in Alfred Hitchcock's American Movies Jason T. McEntee

Chapter 3

The Child Who Knew Too Much: Liminality in Alfred Hitchcock's The Man Who Knew Too Much $(1934,1956)$

D. Elizabeth Ramsey

Chapter 4

No Laughing Matter: Imperiling Kids and Country in

Alfred Hitchcock's Sabotage (1936)

Peter W. Lee

Chapter 5

"If You Rip the Fronts Off Houses": Killing Innocence in Alfred Hitchcock's Shadow of a Doubt (1943) 
Chapter 6

Daddy's Girl: The Knowing Innocent in

Strangers on a Train (1951)

Brian Walter

Chapter 7

Renegotiating Romanticism and the All-American Boy

Child: Alfred Hitchcock's The Trouble with Harry (1955)

Adrian Schober

Chapter 8

Between Knowingness and Innocence: Child Ciphers in

Alfred Hitchcock's Marnie (1964) and The Birds (1963)

161

Fran Pheasant-Kelly

Chapter 9

The Child Hero in Alfred Hitchcock's The Birds (1963)

Samantha Lay

Chapter 10

"It's the End of the World!": The Influence of

The Birds on the Evil Child Film

Craig Martin

Chapter 11

Psycho without a Cause: Norman Bates and Juvenile

Delinquency Cinema

Kevin J. Wetmore, Jr.

Chapter 12

Alfred Hitchcock's Stylized Capture of

Postadolescent Fatheads

William Thomas McBride

Notes on Contributors

Index 


\section{Illustrations}

12.1 Troubled Jonathan Drew (Ivor Novello) is captured by Hitchcock's first fathead shot, The Lodger (1927)

12.2 A near graphic match of fathead shots between Ramon (1934)

12.3 Devlin, Notorious (1946)

12.4 Sebastian of Notorious (1946) 244

12.5 Verloc of Sabotage (1936)

12.6 A fathead shot of tiny, boy-like Scotty sitting quietly in his chair, Vertigo (1958)

12.7 A recumbent fathead, Spellbound (1945)

12.8 Another recumbent fathead, Rear Window (1954)

12.9 "Horrible, faded, fat, greedy women. Are they human, or are they fat, wheezing animals? Hm?" Shadow of a Doubt (1943)

12.10 The fathead literally sticks his neck out to resemble one of his stuffed predatory owls, Psycho (1960)

12.11 Tippi Hedren is afforded judgmental fathead shots in The Birds (1963) and Marnie (1964)

12.12 Breaking through his hardboiled armor, the former fathead, William Callew (Joseph Cotton), is saved by his own tears in "Breakdown" (first broadcasted 11/13/55) Alfred Hitchcock Presents 
This page intentionally left blank 